\title{
ANALISIS PENDAPATAN DAN STRATEGI PENGEMBANGAN TAHU DI KELURAHAN ABIAN TUBUH KECAMATAN SANDUBAYA KOTA MATARAM
}

\section{REVENUE ANALYSIS AND STRATEGY OF EXTENSIVE SOYBEAN IN THE VILLAGE ABIAN TUBUH SUBDISTRICT SANDUBAYA CITY MATARAM}

\author{
Nurlaila, Anwar, dan Bambang Dipokusumo \\ Program Studi Agribisnis Fakultas Pertanian Unram
}

\begin{abstract}
ABSTRAK
Penelitian ini bertujuan untuk mengetahui besarnya biaya, penerimaan dan pendapatan agroindustri tahu, mengetahui faktor internal dan eksternal yang dapat mempengaruhi pengembangan agroindustri tahu di Kelurahan Abian Tubuh, mengetahui alternatif strategi yang dapat diterapkan dalam mengembangkan agroindustri tahu di Kelurahan Abian Tubuh, dan mengetahui perioritas strategi yang dapat diterapkan dalam mengembangkan agroindustri tahu di Kelurahan Abian Tubuh. Metode dasar yang digunakan dalam penelitian ini adalah metode deskriptif dan dilaksanakan dengan teknik survei. Metode penentuan lokasi penelitian dilakukan secara purposive (sengaja), yaitu Kelurahan Abian Tubuh karena di kelurahan tersebut terdapat jumlah industri tahu yang paling banyak. Jenis data yang digunakan dalam penelitian ini adalah data primer dan data sekunder. Metode analisis data yang digunakan adalah (1) analisis usaha untuk mengetahui besarnya biaya, penerimaan dan pendapatan usaha, (2) analisis SWOT untuk mengidentifikasi faktor internal dan eksternal yang menjadi kekuatan, kelemahan, peluang dan ancaman dalam pengembangan usaha, (3) matriks SWOT untuk merumuskan alternatif strategi pengembangan usaha. Dari hasil penelitian diketahui bahwa : Kekuatan utama dalam mengembangkan industri tahu yaitu jumlah modal yang dikelola, SDM pembuat tahu sudah berpengalaman lebih dari 10 tahun. Sedangkan kelemahan utamanya yaitu kurangnya subsidi kedelai dan belum ada standarisasi produk tahu. Peluang dalam mengembangkan industri tahu yaitu kualitas bahan baku dan kepercayaan konsumen. Sedangkan ancamannya yaitu kenaikan harga sembako dan kurangnya pasokan kayu sebagai bahan bakar akibat musim hujan.
\end{abstract}

Kata kunci: analisis pendapatan dan strategi pengembangan 


\begin{abstract}
This research aim to know cost, acceptance, earnings industries of soybean, to know internal and eksternal factor which can influence industries development of soybean in The Village Abian Tubuh, knows alternative of applicable strategy in developing industries of soybean in The Village Abian Tubuh, and knows applicable strategy priority in developing industries of soybean in The Village Abian Tubuh. Basic method applied in this research is descriptive analytic method and used with technique survey. Determination method of research is done in purposive, that is The Village Abian Tubuh because the most of industries of soybean in this area located. Data type applied in this research is primary data and secondary data. Data analysis method applied is (1) business analysis to know level of cost, revenue and operating income, (2) anlysis of SWOT to identify internal and external factor becoming strength, weakness, opportunity and threat in development of business, (3) matrix SWOT to formulate alternative development strategy of business. From result of research it is known that : the amount of capital being managed and human resources experienced over 10 years. While main weakness is subsidy the soy less and no standarisation soybean product. Opportunity in developing industries of soybean that is raw material quality and costumers believe. While the threat is to increase of the price of sembako and the lack of preparation of wood as of fuel due to the rainy season.
\end{abstract}

Keywords: Revenue analysis and strategy of extensive 


\section{PENDAHULUAN}

Semakin sempitnya lapangan pekerjaan di Indonesia, mendorong kita untuk dapat menciptakan lapangan pekerjaan sendiri, maka dari itu sangat penting untuk menemukan lahan pekerjaan baru diantaranya adalah agroindustri.

Salah satu agroindustri yang dapat dilestarikan dan dikembangkan baik kualitas dan kuantitasnya adalah agroindustri tahu kedelai. Agroindustri tahu kedelai merupakan agroindustri rumah tangga yang mengolah kedelai menjadi tahu melalui proses olahan secara sederhana akan tetapi memiliki nilai ekonomi yang cukup tinggi dan merupakan salah satu komoditas yang dapat diandalkan di daerah Abian Tubuh.

Kedelai adalah salah satu jenis tanaman palawija yang merupakan tanaman pangan terpenting setelah jagung dan ubi kayu. Kedelai merupakan makanan penting sebagai sumber protein nabati. Produksi kedelai dimanfaatkan sebagai konsumsi masyarakat, makanan ternak, bahan baku insdustri seperti tempe, tahu, kecap, susu kedelai, minyak goreng, dan sebagai masukan dalam usahatani berupa benih. Kedelai dapat digunakan sebagai salah satu alternatif lain guna memenuhi kebutuhan pangan penduduk, mengingat kangdungan gizi yang terdapat pada biji kedelai cukup tinggi. Dalam 100 gram biji kedelai mengandung 330 kalori, 35 gram protein, 12 gram lemak, 35 gram karbohidrat dan 8 gram air sehingga baik untuk kesehatan manusia (Suprapto, 1991; Kasrino, 1985).

Kebutuhan protein akan terus meningkat seiring peningkatan jumlah penduduk dan pendapatan, sedangkan dipihak lain penyediaan sumber protein di Indonesia masih belum mencukupi. Untuk itu diperlukan sumber protein pengganti yang murah dan mudah. Melihat kandunggan gizi yang dimiliki, kedelai memiliki potensi yang amat besar sebagai sumber utama protein bagi masyarakat Indonesia. Sebagai sumber protein yang tidak mahal, kedelai telah lama dikenal dan digunakan dalam beragam produk makanan yang biasa kita kenal sebagai produk bahan baku dari berbagai industri (Amang B; Sawit dan Rachman; 1996).

Melihat peranan kedelai sebagai sumber protein dan bahan baku industri, maka kedelai tetap dipandang penting oleh pemerintah. Ini dapat dibuktikan dengan kesungguhan pemerintah dalam memperhatikan kedelai dapat dilihat pada satu gerakan yang diberi nama "Gema Palanggung 2001". Gerakan ini bertujuan untuk meningkatkan produksi kedelai, padi dan jagung sehingga dicapi swasembada palanggung dan swasembada kedelai menurut gerakan ini direncanakan pada tahun 2001 (Hafsah, 1998). 


\section{METODE PENELITIAN}

\section{Metode Penelitian}

Metode yang digunakan dalam penelitian ini adalah metode deskriptif yaitu metode yang bertujuan untuk memecahkan masalah yang ada pada waktu sekarang dengan cara mengumpulan data, menyusun, menganalisis dan menginterpretasikan data untuk mencapai suatu kesimpulan. Sedangkan teknik pengumpulan data yang digunakan adalah dengan teknik survei yaitu dengan wawancara langsung dan dengan menggunakan daftar pertanyaan yang telah dipersiapkan sebelumnya (Nazir, 1993).

\section{Penentuan Daerah Sampel}

Penelitian ini akan dilaksanakan di Kecamatan Sandubaya. Kecamatan Sandubaya terdiri dari tujuh kelurahan, dan dari tujuh kelurahan dipilih satu kelurahan yaitu kelurahan Abian Tubuh sebagai daerah sampel dengan teknik purposive sampling (sengaja) atas dasar pertimbangan bahwa kelurahan tersebut memiliki unit usaha tahu paling banyak yang terdaftar di Disperindag Provinsi NTB.

\section{Penentuan Responden}

Jumlah responden ditentukan dengan proporsional random sampling yakni mengambil seluruh populasi yang ada sebanyak 30 orang. Dan untuk menentukan responden pada masing-masing sampel dilakukan dengan memilih sampel secara spontanitas atau siapa saja yang dianggap dapat mewakili populasi berdasarkan kriteria yang ditetapkan. Responden dalam penelitian ini adalah 30 pengusaha tahu yang berdomisili di Kelurahan Abian Tubuh.

\section{Analisis Data}

a. Biaya Produksi

Biaya yang diperhitungkan dalam penelitian ini adalah biaya yang benar-benar dikeluarkan dalam usaha produksi tahu. Nilai total biaya pada usaha industril tahu adalah penjumlahan dari nilai total biaya tetap (TFC) dan nilai biaya variabel (TVC) yang digunakan dalam kegiatan produksi tahu.

$$
\mathrm{TC}=\mathrm{TFC}+\mathrm{TVC}
$$


Dimana

TC = biaya total usaha industri tahu (Rupiah)

TFC = total biaya tetap usaha industri tahu (Rupiah)

$\mathrm{TVC}=$ total biaya variabel usaha industri tahu (Rupiah)

b. Penerimaan Usaha

Hasil produksi berupa tahu yang keseluruhannya dijual. Penerimaan usaha produksi tahu (TR) merupakan hasil kali antara produksi yang diperoleh (Y) dengan harga jual (Py).

$$
\mathrm{TR}=\mathrm{Y} . \mathrm{Py}
$$

c. Pendapatan Usaha

Pendapatan usaha produksi tahu (Pd) adalah selisih antara penerimaan yang diperoleh dari usaha produksi tahu dengan semua biaya yang benar-benar dikeluarkan dalam usaha produksi tahu.

$$
\mathrm{Pd}=\mathrm{TR}-\mathrm{TC}
$$

\section{d. Analisis SWOT}

Analisis IFAS dan EFAS digunakan untuk mengetahui faktor internal dan eksternal usaha pemasaran tanaman hias dan menggunakan metode Paired Comparison untuk menentukan skor pada tiap-tiap faktor. Bobot setiap variabel diperoleh dengan menggunakan nilai setiap variabel terhadap jumlah nilai keseluruhan variabel dengan menggunakan rumus oleh Kinnear dan Taylor (1991). Analisis SWOT digunakan untuk membandingkan antara faktor eksternal peluang dan ancaman dengan faktor internal kekuatan dan kelemahan sehingga diperoleh strategistrategi baru dari masing-masing faktor eksternal dan internal. 


\section{HASIL DAN PEMBAHASAN}

\section{Biaya Produksi}

Biaya adalah sejumlah nilai uang yang dikeluarkan oleh pengusaha untuk membiayai kegiatan usahanya. Biaya yang diperhitungkan dalam penelitian ini adalah biaya yang benar-benar dikeluarkan oleh pengusaha dalam produksi tahu selama satu kali produksi meliputi biaya tetap dan biaya variabel. Rata-rata biaya dalam proses produksi perhari agroindustri tahu di Kelurahan Abian Tubuh disajikan pada Tabel 1.

Tabel 1. Rata-rata Biaya Produksi Tahu di Kelurahan Abian Tubuh Selama 1 hari

\begin{tabular}{|c|c|}
\hline Uraian & Rata-rata $(\mathrm{Rp})$ \\
\hline 1. Biaya Variabel & 935.510 \\
\hline 2. Biaya Tetap & 35.253 \\
\hline Jumlah & 970.763 \\
\hline
\end{tabular}

Rata-rata biaya produksi pada agroindustri tahu per hari sebesar Rp 970.763, yang teridiri biaya variabel sebesar Rp 935.510 dan biaya tetap sebesar $R p$ 35.253. Secara rinci biaya produksi usaha agroindustry tahu diuraikan pada bahasan berikut.

\section{Biaya Variabel}

Biaya variabel merupakan biaya yang dikeluarkan yang habis terpakai dalam satu kali proses produksi dan dipengaruhi oleh besar kecilnya jumlah produksi.

Tabel 2. Rata-rata Biaya Sarana Dalam Produksi Usaha Agroindusti Tahu di Kelurahan Abian Tubuh Per hari Tahun 2015

\begin{tabular}{|c|c|c|c|}
\hline $\begin{array}{c}\text { Jenis Biaya } \\
\text { Sarana Produksi }\end{array}$ & $\begin{array}{c}\text { Jumlah } \\
\text { Fisik }\end{array}$ & $\begin{array}{l}\text { Harga/Unit } \\
\text { (Rp) }\end{array}$ & $\begin{array}{c}\text { Biaya Variabel } \\
\text { Perhari (Rp) }\end{array}$ \\
\hline $\begin{array}{l}\text { 1. Bahan Baku Kedelai } \\
(\mathrm{Kg})\end{array}$ & 105 & 7.500 & 788.750 \\
\hline $\begin{array}{l}\text { 2. Kayu serut, kayu bakar, } \\
\text { ampas kacang (Unit) }\end{array}$ & 8 & 10.000 & 83.333 \\
\hline 3. Solar/bensin (Liter) & 4 & 6.500 & 25.133 \\
\hline $\begin{array}{l}\text { 4. Larutan Garam/air } \\
\text { pasir padak }\end{array}$ & 24 & 1.600 & 38.293 \\
\hline Jumlah & - & - & 935.510 \\
\hline
\end{tabular}

\section{Biaya Tetap}

Biaya tetap merupakan biaya yang dikeluarkan yang tidak habis terpakai dalam satu kali proses produksi dan tidak dipengaruhi oleh besar kecilnya jumlah produksi. 
Tabel 3. Rata-rata Biaya Tetap Dalam Produksi Tahu di Kelurahan Abian Tubuh Per hari Tahun 2015

\begin{tabular}{|c|c|c|}
\hline Jenis Biaya & $\begin{array}{c}\text { Jumlah } \\
\text { (Unit) }\end{array}$ & Rata-rata biaya tetap \\
\hline 1.Penyusutan Peralatan & 1 & 601 \\
a. Mesin tepung & 1 & 350 \\
b. Wajan besar & 3 & 341 \\
c. Alat cetak & 3 & 36 \\
d. Kain saring & 33 & 2148 \\
e. Kelabang/nyiur & 1 & 73 \\
f. Kotak box & 21 & 1288 \\
g. Ember & 2 & 417 \\
h. Drum & - & $\mathbf{5 . 2 5 3}$ \\
\hline Jumlah biaya penyusutan alat & - & 10.000 \\
\hline 2. Tagihan listrik & - & 20.000 \\
\hline 3. Tagihan air PDAM & & $\mathbf{3 0 . 0 0 0}$ \\
\hline Jumlah 2-3 & & $\mathbf{3 5 . 2 5 3}$ \\
\hline Jumlah & & \\
\hline
\end{tabular}

\section{Penerimaan dan Pendapatan}

Pendapatan merupakan selisih antara penerimaan dan biaya produksi selama satu kali proses produski.

Tabel 4. Rata-rata Penerimaan dan Pendapatan Produsen Agroindustri Tahu di Kelurahan Abian Tubuh per hari tahun 2015

\begin{tabular}{|l|r|r|}
\hline Uraian & Jumlah & Rata-rata \\
\hline 1. Produksi tahu (unit) & 96.330 & 3.211 \\
\hline 2. Harga tahu (Rp/unit) & 25.150 & 838 \\
\hline 3. Total Biaya produksi (Rp) & 29.122 .905 & 970.763 \\
\hline 4. Penerimaan (Rp) & 58.990 .000 & 1.966 .333 \\
\hline 5. Pendapatan (Rp) & 29.687 .095 & 995.570 \\
\hline
\end{tabular}

Tabel 4 menjelaskan bahwa rata-rata produksi yang dihasilkan produsen pada usaha agroindustri tahu sebesar 96.330 unit dalam sekali proses produksi atau rata-rata per hari 3.211 unit, dengan harga jual yang berlaku sebesar Rp 25.150/unit atau ratarata $\mathrm{Rp}$ 838/unit sehingga nilai produksi (penerimaan) yang diperoleh produsen agroindustri tahu sebesar Rp 58.990.000 per proses produksi atau Rp 1.966 .333 per hari. Biaya produksi yang dikeluarkan sebesar Rp 29.122.905 per proses produksi atau rata-rata Rp 970.763 selama satu hari sehingga pendapatan yang diperoleh produsen sebesar Rp 29.687.095 per proses produksi atau Rp 995.570 selama satu hari produksi. 


\section{Identifikasi Faktor Kekuatan dan Kelemahan Agroindustri Tahu}

Dalam suatu perusahaan, apakah itu perusahaan besar ataupun perusahaan kecil tentu memiliki suatu kekuatan, kelemahan, peluang dan ancaman. Analisis lingkungan internal yang dilakukan yaitu terhadap faktor-faktor strategi internal yang terdiri dari kekuatan dan kelemahan dalam usaha agroindustri tahu. Analisis lingkungan eksternal adalah suatu proses yang digunakan perencana strategi untuk memantau faktor lingkungan eksternal dalam menentukan peluang dan ancaman terhadap usaha agroindustri tahu. Dengan demikian usaha agroindustri dapat memanfaatkan peluang secara efektif dan dapat menangani ancaman dari luar.

Matrik IFAS (Internal Strategic Faktor Analysis Summary) kekuatan dan kelemahan agroindustri tahu di Kelurahan Abian Tubuh Kecamatan Sandubaya

\begin{tabular}{|c|c|c|c|c|}
\hline Faktor-faktor Strategi Internal & Bobot & Rating & $\begin{array}{l}\text { Bobot X } \\
\text { Rating }\end{array}$ & Komentar \\
\hline (1) & (2) & (3) & (4) & (5) \\
\hline A. Kekuatan & & & & \multirow{8}{*}{$\begin{array}{l}\text { Sebagian besar } \\
\text { pengusaha tahu di } \\
\text { Kelurahan Abian Tubuh } \\
\text { sudah berpengalaman } \\
\text { lebih dari } 10 \text { tahun } \\
\text { karena usaha tahu } \\
\text { tersebut termasuk usaha } \\
\text { turun menurun }\end{array}$} \\
\hline 1. Jumlah modal yang dikelola & 0,17 & 4 & 0,68 & \\
\hline $\begin{array}{l}\text { 2. SDM pembuat tahu sudah } \\
\text { berpengalaman }>10 \text { tahun }\end{array}$ & 0,18 & 4 & 0,72 & \\
\hline $\begin{array}{l}\text { 3. Jalan raya di Abian Tubuh } \\
\text { cukup memdai }\end{array}$ & 0,12 & 3 & 0,36 & \\
\hline 4. Penyuluhan tentang limbah tahu & 0,07 & 4 & 0,27 & \\
\hline $\begin{array}{l}\text { 5. Cukup memahami manajemen } \\
\text { produksi yang baik }\end{array}$ & 0,12 & 4 & 0,48 & \\
\hline $\begin{array}{l}\text { 6. Pengawasan terhadap } \\
\text { ketersediaan bahan baku }\end{array}$ & 0,18 & 4 & 0,74 & \\
\hline 7. Infrastruktur sudah baik & 0,18 & 4 & 0,64 & \\
\hline Jumlah & 1,00 & & 3,88 & \\
\hline B. Kelemahan & 0.16 & 3 & 0,58 & \multirow{7}{*}{$\begin{array}{l}\text { Kurangnya subsidi } \\
\text { kedelai dalam negeri } \\
\text { sehingga pengusaha tahu } \\
\text { harus mengimpor kedelai } \\
\text { dari luar agar tetap } \\
\text { melakukan produksi }\end{array}$} \\
\hline $\begin{array}{l}\text { 2. Belum ada standarisasi produk } \\
\text { tahu }\end{array}$ & 0,11 & 1 & 0,12 & \\
\hline $\begin{array}{l}\text { 3. SDM pengusaha dan } \\
\text { pemerintah terbatas }\end{array}$ & 0,16 & 3 & 0,49 & \\
\hline $\begin{array}{l}\text { 4. Belum adanya bantuan } \\
\text { permodalan dan peralatan dari } \\
\text { pemerintah }\end{array}$ & 0,10 & 1 & 0,06 & \\
\hline $\begin{array}{l}\text { 5. Pemerintah fokus terhadap } \\
\text { limbah, tetapi tidak } \\
\text { memperhatikan masalah } \\
\text { produksi }\end{array}$ & 0,15 & 2 & 0,36 & \\
\hline $\begin{array}{l}\text { 6. Kurangnya data dari } \\
\text { Disperindag }\end{array}$ & 0,16 & 2 & 0,27 & \\
\hline $\begin{array}{l}\text { 7. Pengendalian internal yang } \\
\text { dimiliki pengusaha tahu masih } \\
\text { lemah (belum memiliki sistem } \\
\text { pengelolaan risiko) }\end{array}$ & 0,16 & 3 & 0,43 & \\
\hline Jumlah & 1,00 & & 2,31 & \\
\hline Total Faktor Strategis Internal & & & 1.57 & \\
\hline
\end{tabular}


Berdasarkan hasil analisis tabel di atas dapat dilihat bahwa total skor pembobotan faktor internal sebesar 1,57, hal ini mengindikasikan bahwa usaha agroindustri tahu di Kelurahan Abian Tubuh Kecamatan Sandubaya berada pada posisi kuat, dimana kekuatan yang dimiliki sudah digunakan secara optimal untuk mengatasi kelemahan yang ada.

Selain ditentukan oleh faktor internal, strategi pengembangan agroindustri tahu di Kelurahan Abian Tubuh juga ditentukan oleh faktor eksternal. Hasil evaluasi faktor eksternal (EFAS) disajikan pada tabel berikut.

Matriks EFAS (Eksternal Strategic Factor Analysis Summary) Agroindustri Tahu di Kelurahan Abian Tubuh Kecamatan Sandubaya

\begin{tabular}{|c|c|c|c|c|}
\hline Faktor-faktor strategi eksternal & Bobot & Rating & $\begin{array}{c}\text { Bobot X } \\
\text { Rating }\end{array}$ & Komentar \\
\hline$(1)$ & (2) & (3) & (4) & $(5)$ \\
\hline $\begin{array}{l}\text { A. Peluang } \\
\text { 1. Kondisi lingkungan yang aman } \\
\text { 2. Tren pasar yang sesuai dengan } \\
\text { industri tahu } \\
\text { 3. Ketersediaan teknologi uap } \\
\text { 4. Perkembangan teknologi } \\
\quad \text { pengolahan pangan } \\
\text { 5. Kualitas bahan baku } \\
\text { 6. Kepercayaan konsumen } \\
\text { 7. Permintaan tahu stabil } \\
\end{array}$ & $\begin{array}{l}0,10 \\
0,19 \\
0,10 \\
0,09 \\
0,19 \\
0,19 \\
0,15 \\
\end{array}$ & $\begin{array}{l}3 \\
4 \\
3 \\
4 \\
\\
4 \\
4 \\
3 \\
\end{array}$ & $\begin{array}{l}0,29 \\
0,75 \\
\\
0,30 \\
0,37 \\
\\
0,75 \\
0,75 \\
0,44\end{array}$ & $\begin{array}{l}\text { Mempertahankan } \\
\text { kepercayaan } \\
\text { konsumen dengan } \\
\text { cara memper- } \\
\text { tahankan kualitas } \\
\text { tahu }\end{array}$ \\
\hline Jumlah & 1,00 & & 3,66 & \\
\hline $\begin{array}{l}\text { B. Ancaman } \\
\text { 1. Kenaikan harga kedelai dan } \\
\text { sembako } \\
\text { 2. Lingkungan produksi yang kurang } \\
\text { baik } \\
\text { 3. Kurangnya pasokan kayu sebagai } \\
\text { bahan bakar akibat musim hujan } \\
\text { 4. Tidak ada inovasi pada rasa tahu }\end{array}$ & $\begin{array}{l}0,24 \\
0,29 \\
0,26 \\
0,20\end{array}$ & $\begin{array}{l}4 \\
2 \\
3\end{array}$ & $\begin{array}{l}0,97 \\
0,59 \\
0,75 \\
0,61\end{array}$ & $\begin{array}{l}\text { Segera mengatasi } \\
\text { ancaman dengan } \\
\text { cara stabilkan harga } \\
\text { pasar, dan } \\
\text { mengganti bahan } \\
\text { bakar dengan } \\
\text { menggunakan kayu } \\
\text { serut, akan tetapi } \\
\text { dalam rasa belum } \\
\text { ada inovasi untuk } \\
\text { menciptakan rasa } \\
\text { lainnya }\end{array}$ \\
\hline Jumlah & 1,00 & & 2,92 & \\
\hline Total Faktor Strategis Eksternal & & & 0,74 & \\
\hline
\end{tabular}

Berdasarkan hasil analisis tabel di atas dapat dilihat bahwa total skor pembobotan faktor eksternal sebesar 0,74 , hal ini mengindikasikan usaha agroindustri tahu di Kelurahan Abian Tubuh Kecamatan Sandubaya berada pada posisi eksternal yang lemah, dimana peluang yang dimiliki belum dimanfaatkan secara optimal untuk mengatasi ancaman yang dihadapi. 


\section{KESIMPULAN DAN SARAN}

\section{Kesimpulan}

Terbatas dari lingkup penelitian ini dapat ditarik kesimpulan sebagai berikut :

1. Rata-rata penerimaan yang diperoleh pengusaha tahu dalam 1 hari proses produksi sebesar Rp 1.966.333 dengan biaya produksi sebesar Rp 970.763 dan pendapatan sebesar Rp 995.570 sehingga usaha tahu di Kelurahan Abian Tubuh memiliki prospek untuk dikembangkan oleh pemerintah Kota Mataram.

2. Faktor internal yang dapat mempengaruhi pengembangan industri kecil tahu di Kelurahan Abian Tubuh Kecamatan Sandubaya adalah jumlah modal yang dikelola, SDM pembuat tahu sudah berpengalaman >10 tahun, jalan raya di Abian Tubuh cukup memadai, pengawasan terhadap ketersediaan bahan baku, penyuluhan tentang limbah tahu, cukup memahami manajemen produksi yang baik, infrastruktur sudah baik, kurangnya subsidi kedelai, rasa tahu, belum ada standarisasi produk, SDM pengusaha dan pemerintah terbatas, belum adanya bantuan permodalan dan peralatan dari pemerintah, pemerintah fokus terhadap limbah tetapi tidak memperhatikan masalah produksi, kurangnya data dari Disperindag, pengendalian internal yang dimiliki pengusaha tahu masih lemah (belum memiliki sistem pengolaan risiko). Faktor eksternal yang dapat mempengaruhi pengembangan industri kecil tahu di Kelurahan Abian Tubuh Kecamatan Sandubaya adalah tren pasar yang sesuai dengan industri tahu, kondisi lingkungan yang aman, ketersediaan teknologi uap, perkembangan teknologi pengolahan pangan, kualitas bahan baku, kepercayaan konsumen, permintaan tahu stabil, kenaikan harga sembako, lingkungan produksi kurang baik.

3. Alternatif strategi yang dapat diterapkan dalam mengembangkan industri kecil tahu di Kelurahan Abian Tubuh Kecamatan Sandubaya adalah memanfaatkan modal sendiri, ketersediaan bahan baku, pengawasan kualitas kedelai untuk menambah kepercayaan konsumen melalui teknologi yang ada. Perbaikan kebijakan serta kualitas penyuluhan sesuai kebutuhan pengusaha tahu meningkatkan kualitas dan kuantitas sumber daya manusia melalui kegiatan pembinaan untuk memaksimalkan potensi industri tahu.

\section{Saran}

1. Pengusaha tahu sebaiknya mulai melakukan inovasi terhadap produksi tahu, baik mengenai rasa, ketahanan dan kualitas agar dapat menarik lebih banyak konsumen dan usaha tahu ini dapat berkembang.

2. Pengusaha tahu sebaiknya menjaga kebersihan baik dari proses pembuatan tahu hingga ke penjual produk tahu.

3. Pemerintah harus turut membantu pengembangan usaha tahu, peningkatan kualitas dan mutu tahu atau proses pemasaran dan infrastruktur yang dibutuhkan produsen tahu. 
4. Untuk menjaga kepercayaan konsumen, pemerintah diharapkan member standarisasi produk tahu agar para produsen memiliki pedoman yang sah dalam produksi tahu.

\section{DAFTAR PUSTAKA}

Sulistiyo, A., 2004. skripsi. Fakultas Pertanian Universitas Mataram. Analisis Ekonomi Usaha Agroindustri Tahu dan Tempe di Kota Bima.

Amang B, dan Sawit M.H., 1996. Ekonomi Kedelai di Indonesia IPB Press. Bogor.

Badan Pusat Statistik Provinsi NTB, 2005. NTB Dalam Angka. BPS NTB. Mataram.

David, F. R. 2004. Manajemen Strategis Konsep-Konsep. PT. Indeks Kelompok Gramedia. Jakarta.

Dinas Pertanian, Perkebunan dan Peternakan Kabupaten Lombok Barat, 2012. Daftar Luas Areal dan Produksi Komoditi Perkebunan Dirinci per Kecamatan di provinsi NTB tahun 2012 (Triwulan III).

Disperindag Provinsi NTB, 2011. Data Potensi Industri Kecil Menengah Provinsi Nusa Tenggara Barat Tahun 2011. Mataram - NTB.

Djuwari. 1994. Aspek-Aspek Ekonomi Usahatani. Program Pasca Sarjana UGM. Yogyakarta.

Downey, W.D. dan S.P. Erickson, 1992. Manajemen Agribisnis. Erlangga, Jakarta.

Fadholi, H. 1989. Ilmu Usahatani. Penebar Swadaya. Jakarta.

Hafsah, M, J., 1998.Visi dan Misi Gema Pelanggung 2001 Sebagai Impelementasi Binas Inbis. Bahan Pelatihan Untuk Penelitian Program Aksi Pemberdayaan Masyarakat Tani Menuju Ketahanan Pangan Nasional. Bogor.

Hetzel, S. and Tony, S. 2007. Melonjak dari SWOT: Empat Pelajaran Setiap Rencana Strategis Harus Tahu. AI Practitioner: International Journal of AI Praktek Is The Best. www.innovationpartners.com. Diakses 15 April 2010.

Irwan Setiawan, 2012. Analisis Usaha dan Pemasaran Agroindustri Tahu di Kota Mataram.

Kamisius, Anggota Ikapi 1989. AAK Kedelai. Yogyakarta Percetakan Kamisius. Yogyakarta.

Kasrino, F. 1985. Pemasaran Kedelai di Indonesia. Balai Penelitian dan Pengembangan Pertanian. Pusat Penelitian dan Pengembangan Tanaman. Bogor. 37-72 h.

Kinnear, T.L., dan Taylor, 1991. Marketing Research, Analysis Applied Approach. Fourth Edition. Mc. Graw Hill. USA.

Pearce, A. J. and B. R. Robinson. 2008. Manajemen Strategis Edisi 10. Salemba Empat. Jakarta.

Rangkuti, F., 2013. Analisis SWOT; Teknik Membedah Kasus Bisnis. Cetakan Ketigabelas. PT. Gramedia Pustaka Utama. Jakarta. 